\title{
DIALOGUE IN FICTION: THE SYNTACTIC LEVEL
}

\author{
Iryna MYKYTIUK, Olesia MUSURIVSKA \\ Yuriy Fedkovych National University, Chernivtsi, Ukraine
}

\begin{abstract}
The article explores the syntactic peculiarities of dialogue in fiction. We focus on three such features: structural types of sentences, communicative types of sentences, and syntactic stylistic devices. Simple sentences have a distinct advantage in the characters' conversation due to the fact that they allow the speakers to express their thoughts concisely and clearly thus ensuring the effectiveness of interpersonal communication. The quantitative distribution of communicative types of sentences in the dialogue may be explained by the fact that in the course of conversation the speakers/characters try to learn something they are interested in (interrogative sentences) and to notify the addressee about something important (declarative sentences). The prevalent use of elliptical constructions and aposiopeses reflects the natural omissions that occur in colloquial speech. Thus, at syntactic level, the conversation in fiction bears resemblance to colloquial speech.
\end{abstract}

Keywords: characters' speech, dialogic communication, structural types of sentences, communicative types of sentences, syntactic stylistic devices

\section{Introduction}

Different aspects of literary dialogue have been a point of research for many scholars both in Ukraine and abroad. Theoretical critics have explored the correlation between dialogue, monologue and polylogue in a literary text (Bakhtin 1975; Yakubinskiy 1986), analyzed the peculiarities of spontaneous and conversational dialogue (Dolinin 2010; Zemskaya 2011), investigated the interaction of the author's and the characters' speech in literary prose and drama (Khalizev 2002), addressed the language peculiarities of the characters' speech (Igina 2009), the gender aspect (Nera 2017), social and status characteristics (Borysenko 2013), communicative styles (Antonov 2017) etc. Yet some issues concerning the syntactic peculiarities of the characters' speech in dialogic 
excerpts of literary discourse need further elaboration. The objective of this article is to reveal syntactic peculiarities and organization of dialogue in modern English fiction.

\section{Literature review}

The structure of a literary discourse is a unity of significant stylistic centers such as the author and the character, in which the author serves as an organizing center of the literary discourse, while the character is the main object of literary portrayal. Yelena Goncharova claims that this unity is ensured by the regularities of development of a literary text's composition and architectonics (44). Monologic and dialogic texts are differentiated on the basis of a clearly determined structure that underlies each speech situation, as well as on the basis of the regularities of text formation. Anatoliy Zahnitko and Iryna Domracheva argue:

The differences in the structure of the speech situation are determined by the distribution of roles between the speech act participants. Monologic text is an oral or written speech of one person, the other participant of the speech act - the addressee, the recipient, is either fancied or does not react immediately (linear chain of sentences). Dialogic text represents an alternative chain that is formed by the alternation of utterances of two or several speech participants. (23)

Similar ideas are expressed by Nina Valgina (170) who claims that monologue is a first-person text, while dialogue is an exchange of utterances belonging to different people. Ilona Romaniuk, in her Ph.D. thesis Dialogue in a narrative text: structural, semantic and stylistic functions, defines dialogue as "the most active form of interpersonal communication which functions as a text generated by the addresser and the addressee in a certain language situation and motivated by the intentions of the speakers" (16). Valeriya Kukharenko, in her book Text Interpretation, treats dialogic unity as consisting of "two (or more) conversational turns closely connected by formal and semantic ties" (175). We view dialogue as a communicative exchange of information involving the expression of thoughts and their perception between two participants in the form of questions and answers.

\section{Data and research methodology}

The research is based on 1000 excerpts of dialogic speech of literary characters. These excerpts were singled out from the novel Rich Man, Poor Man by American writer Irwin Shaw. The methods of investigation comprise: the descriptive method for each specific character of dialogic texts; the method of 
overall selection used to single out the corpus of dialogic fragments from the literary text; the quantitative method for establishing the quantitative characteristics of the syntactic peculiarities of the characters' dialogic speech. The scientific novelty of the research consists in the classification of the structural and communicative types of sentences in characters' dialogic speech, the analysis of the syntactic stylistic devices used in the characters' speech and systematization of the obtained results.

\section{Research findings}

We focus on three syntactic characteristics of dialogue in fiction: structural types of sentences, communicative types of sentences, and syntactic stylistic devices. By structure, sentences are divided into: simple sentences, compound sentences, complex sentences and complex-compound sentences (Kaushanskaya et al. 221). Simple sentences, in turn, are further subdivided into extended and unextended (Kaushanskaya et al. 225). In the text of the proposed novel simple unextended sentences are used in the following instances:

- the conversation of a main character of the novel, Rudolph, with a minor character Boylan: "You will have a loving, beautiful wife," Boylan said, sounding like someone reciting a fairy story for children, "waiting at the station evening to drive you home after your day's work in the city, and handsome, bright children who will love you and whom you will see off to the next war, and..." (Shaw 123).

- the conversation between two main characters - the brothers Rudolph and Thomas Jordache: "You're exaggerating," Rudolph said. "Your friend Boylan wouldn't shake my hand at the cemetery. If you don't shake a man's hand in a cemetery, where the hell would you shake his hand?" (Shaw 329).

Simple extended sentences are used in such dialogic exchanges of the characters:

- the conversation of a main character of the novel, Thomas, with his mistress, Clothilde: "This week," she said, touching his hand on the table, "it is our house." "We can never go out with each other" (Shaw 108).

- the conversation of a main character of the novel, Rudolph, with his nephew Billy about his father Willie: "Maybe he was unhappy about something," he said. He was not there to destroy the possibility of love between father and son. "I guess so. He's unhappy a lot of the time." Billy went on eating (Shaw 284).

Complex sentences are used in text fragments where the characters discuss such topics:

- Willie boasts of having informed Rudolph (Gretchen's brother) of his intention to marry Gretchen: "We can speak frankly," Willie said, grinning. "I have explained everything to Rudy. I have told him that we 
are only technically living in sin. I've told him I have asked for your hand in marriage and that you've rejected me."

"Did you tell him you were married?" she asked (Shaw 131).

The subordinate clauses in the three consecutive sentences above are object clauses.

- Rudolph's girlfriend Jean urges him to answer the telephone call: "Answer it. It'll bother you all day if you don't." "No it won't" (Shaw 276).

The subordinate clause in the example above is an adverbial clause of condition.

- Willie discusses with Gretchen the details of his married life: "Still, there's a brighter side to it. I'm working on a divorce. The lady found other divertissements while daddy was away playing soldier." "Where is she? Your wife?" (Shaw 99).

The subordinate clause in the example above is an adverbial clause of time.

- Thomas informs his brother Rudolph of his unwillingness to stay in his native town after their mother's death: "You must admit it's an improvement on where you stay in New York." "I don't plan to stay there long. Anyway, this is no place for me. The people here look at me as though I'm an animal in the zoo" (Shaw 329).

The subordinate clause in the example above is an adverbial clause of comparison.

- Compound sentences are used in such fragments of dialogue:

Willie tries to assure Gretchen that he, if necessary, can try and look like a girl and in such disguise visit her in her single-sex hostel: "I'm petite and I have a light beard. I could borrow a wig. My father always wanted daughters." "I'm afraid not," Gretchen said (Shaw 98).

Gretchen explains to Rudolph the advantages of living in New-York: "It's awfully tacky," Gretchen said, "but it has one supreme advantage. It's not Port Philip." "I understand what you mean," Rudolph said (Shaw 131). The two clauses of the compound sentences above are coordinated by means of the conjunction and (example 1) and the adversative conjunction but (example 2).

The following compound-complex sentence contains the attributive clause: "Oh, I'm not all bad," Boylan said. "There's one virtue which my family has in abundance and I admire it without reservation." "What's that?" "They're rich. They're verrry, verrry rich" (Shaw 34).

As may be understood from the conversational exchange above, Boylan considers wealth to be a real virtue; graphic means of emphasis - letter multiplication, as in verrry (as well as repetition of this lexeme) - testify to this fact. 
Here is an example of a compound-complex sentence containing an adverbial clause of time: "He's arriving in two weeks. Anyway, it's a different kind of work." "I see," Johnny said. "Making movies is a sacred enterprise and a woman is ennobled when she's sacrificed to it" (Shaw 260).

The use of an object clause in the compound-complex sentence is illustrated by the following example: "We've been doing some checking," Jonny said, "and we figure that in the last year you've stolen roughly seventy thousand dollars apiece from me and Rudy." "You fellas must be kidding," Brad said (Shaw 402).

The results of the quantitative analysis of the structural types of sentences in I. Shaw's novel are presented in the pie chart below.

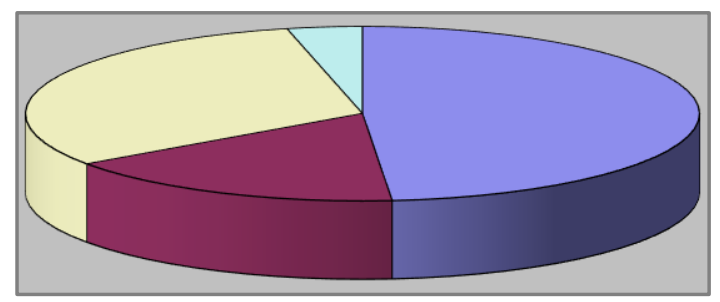

口Simple (486)

口Compound (166)

口Complex (312)

口Compound-complex (36)

Figure 1. Quantitative characteristics of structural types of sentences in I. Shaw's literary discourse

Simple sentences (486 examples - 48.6\%) have a distinct advantage in dialogues due to the fact that they allow the speakers to express their thoughts concisely and clearly, which ensures the effectiveness of interpersonal communication. The speakers use complex sentences (312 examples - 31.2\%) to circumstantiate and specify their thoughts. Compound (166 examples $16.6 \%$ ) and complex-compound (36 examples - 3.6\%) sentences are used in cases when the speakers choose to express themselves in terms of verbose and sophisticated comments concerning people or events that are the subject of the dialogue.

We shall now turn to the communicative types of sentences. According to the purpose of the utterance, sentences are divided into: declarative, interrogative, imperative and exclamatory (Kaushanskaya et al. 221-25). Declarative sentences may have affirmative or negative verb form (Kaushanskaya et al. 221). For example, in the analyzed fictional discourse negative declarative sentences are used in the conversation between Gretchen 
and her father Alex Jordache, when the girl tries to convince him that it is time for her to go to New York and look for a better job:

"I'm not getting anywhere in this job I have," Gretchen said. "And once the war is over, they'll be cutting down and I'll be lucky if I can hang on." "The war's not over yet," Jordache said. There's still a lot of idiots waiting that have to be killed" (Shaw 26).

Affirmative declarative sentences are used in the dialogic fragment depicting Clothilde's bitter confession and her decision not to see Thomas any more:

"I'm a servant," she said. "I lead the life of a servant. I do not want to lose my job or go to jail or go back to Canada. Forget it," she said. "Alles Kaput. It was nice for two weeks. You're a nice boy. I'm sorry I got you into trouble."

"All right, all right," he shouted (Shaw 329).

English interrogative sentences are divided into: general questions, special questions, alternative questions, and disjunctive questions (Kaushanskaya et al. 222-23).

General questions are used in the following fragment: the conversation between Gretchen and Boylan, who is waiting for her near the hospital where she works part-time: "Can I give you a lift, ma'am?" "Thank you very much, no" (Shaw 64).

In Thomas' conversation with his mistress Clothilde some special questions are used; in fact, this conversation is a kind of question-to-question exchange: "Clothilde," Tom said, "why do you work here?" "Where should I work?" (Shaw 108).

Here is an example of an alternative question used in the dialogic speech of the characters in the analyzed discourse - Rudolph is talking to his nephew Billy and Billy's response answers both parts of Rudolph's alternative question: "Do you have to do anything in your room or tell anybody you're going out to lunch with your uncle?" "I have nothing to do," Billy said. "And I don't have to tell anybody anything" (Shaw 284).

A disjunctive question is used in the speech of Boylan, who discusses with Rudolph the plans of the latter for the future: "I see," Boylan said flatly. "You don't aim very high, do you?" "Yes, I do," Rudolph said. "In my own way" (Shaw 178).

An exclamatory sentence in the following example belongs to Boylan, who mocks Rudolph's plans for the summer as well as his utter devotion to his job: "I'm starting work tomorrow at Calderwood's on a full-time basis," Rudolph said. "Poor boy," Boylan said. "What a dreary summer lies ahead of you! I must say your tastes are curious, Rudolph" (Shaw 178).

Rudolph's teacher of French, Miss Lenaut, is forced to use an imperative sentence when she talks to his father Alex Jordache ordering him to leave the classroom: "Get out of here, you low, dirty, common foreigner, and take your 
filthy son with you." "I wouldn't talk like that, Miss," Jordache said, his voice still calm (Shaw 43).

The results of the quantitative analysis of the communicative types of sentences in I. Shaw's literary discourse are presented in the pie chart below.
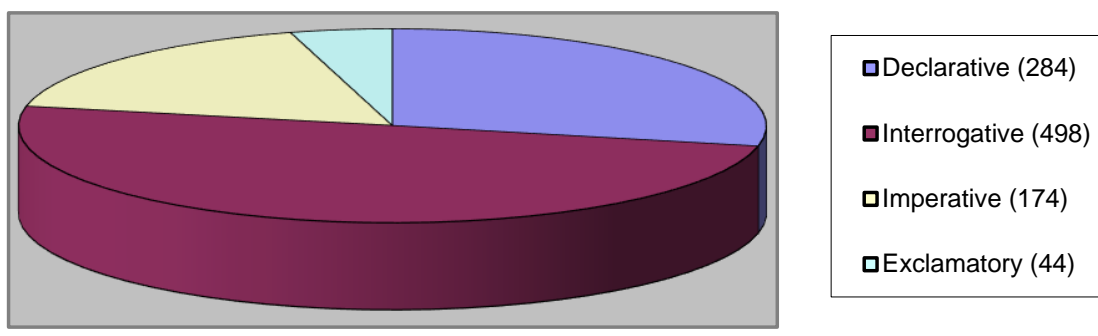

Figure 2. Quantitative characteristics of communicative types of sentences in I. Shaw's discourse

The observed quantitative distribution of the communicative types of sentences in literary dialogues may be explained by the fact that in the course of conversation the speakers try to learn something they are interested in i.e., interrogative sentences (498 fragments - 49.8\%), and to notify the addressee of something important i.e., declarative sentences (284 fragments - 28.4\%). Imperative (174 examples - 17.4\%) and exclamatory (44 fragments - 4.4\%) sentences have proved to be less important in dialogues.

The stylistic range of passages with characters conversation is rather diverse. We will first examine the syntactic stylistic devices based on reduction of the sentence model: ellipsis (deliberate omission of at least one member of the sentence) and aposiopesis (a sudden break in the utterance caused by the strong emotions of the character or his/her reluctance to continue and finish the utterance). Elliptical sentences are used in such fragments of dialogue:

- the conversation of a main character, Gretchen, with a wounded soldier: "How old are you, Arnold?" "Twenty-two. You?" "Nineteen." He grinned. "Good ages, huh?" (Shaw 17).

- the conversation between Rudolph and Gretchen about their parents' reaction to her and Thomas' leaving for good: "Do they talk about me?" Gretchen asked carefully. "Not a word." "And Thomas?" "Gone and forgotten," Rudolph said (Shaw 130).

The following conversational exchanges illustrate the use of the syntactic device of aposiopesis:

- Uncle Harold is so indignant at Thomas' insolent behavior, that he is at a loss for words: "I'm being kind," Uncle Harold said. "I'm being delicate. I am speaking quietly, like a reasonable and forgiving man, 
Tommy. I do not want to make a scandal. I don't want your Aunt Elsa to know her house has been dirtied, that her children have been exposed to... Ach, I can't find the words, Tommy." "I'm not promising anything," Thomas said (Shaw 126).

- Rudolf's girlfriend Julie is so infuriated by his lame excuses (he chooses to spend the evening with Boylan rather than go to the movies with her) that she interrupts him and does not let him finish the sentence: "I just can't," he said. "Anyway, why can't we make it for tomorrow night? The same picture's playing and..." "Go to hell" (Shaw 114).

We now come to the analysis of the syntactic stylistic devices based on the extension of the sentence model. Repetition as a figure of speech means the repetition of part of the utterance. Anaphora, a stylistic device which features repetition of the same word at the beginning of two or more successive sentences or clauses may be traced in the following dialogues:

- Gretchen is trying to persuade Rudolf to leave home: "Get out," she said harshly, "get out before they finish crippling you. Get out of that house where nobody has a friend, where the doorbell never rings." "I'm not crippled," he said (Shaw 81).

In fact, in the dialogue above there are two sets of anaphoric repetition.

- Boylan is trying to practice his usual small talk: "Are you familyridden, Rudolph? Are there ancestors you must not disappoint?" "I have no ancestors," Rudolph said (Shaw 115).

The following dialogues contain examples of epiphora, a syntactic device opposite to anaphora: "A world fit for heroes to live in," he said mockingly, "is hardly fit for Theodore Boylan to live in. You must come and visit me." "Sure," she said. "I'll rhumba on down on my salary from the Boylan Brick and Tile Works" (Shaw 33); "Me?" Thomas said, surprised. "What the hell would I do here?" "You'd find something." Rudolph was careful not to say, "I'll find you something" (Shaw 329).

A variety of repetition - anadiplosis (catch repetition) - is illustrated by the following fragment of interaction (a conversation between Alex Jordache and the priest): "Tell him what you told me," Jordache said. "We know all about it, son," the priest said. "Claude confessed everything to his uncle, as was only right and natural. From confession flows repentance and from repentance forgiveness" (Shaw 73).

Another variety of repetition-framing - may be noticed in the following dialogue (it is Uncle Harold again infuriated by Thomas' affair with Clothilde): "So what? Is that all you have to say, Tommy? So what?" "What do you want me to say?" (Shaw 126). 
Ordinary repetition has no specific place in the sentence, yet it helps the reader to locate the emotional center of the character's utterance and realize the character's communicative intention. For example:

"You must drink more often," he said. "Wine becomes you." He reached over and patted her hand... His hand was dry and firm on her skin. "You're beautiful, pet, beautiful, beautiful."

"I think so, too," she said (Shaw 35).

"There's something written here in French." Jordache pointed with his big index finger to the phrase, 'Je suis folle d'amour,' that Rudolph had printed on the drawing of the blackboard in front of which the naked figure was standing.

"I am crazy with love, I am crazy with love." Miss Lenaut was now striding up and down in short trips behind her desk (Shaw 42).

Parallel constructions are used in the characters' speech in the following dialogues:

"Ain't a dumb kid no more. I know what the score is now and who adds up the numbers. Saw some interesting places, met some interesting folk. You ever been in Cornwall, Miss Jordache? That's in England."

"No" (Shaw 17).

"A boy like Claude," the priest said, "growing up in a Christian home, going to Mass every Sunday, would never dream up a desperate scheme like that on his own."

"Okay," Thomas said (Shaw 73).

A variety of parallel constructions - chiasmus (reversed parallelism) - appears in several successive conversations between the priest Tinker and Alex Jordache, and Alex Jordache and Thomas:

"I wouldn't like to be overheard," he said.

"As far as I can tell," Jordache said, "we got nothing to say to each other that the whole goddamn town can't hear. I don't owe you any money and you don't owe me none" (Shaw 71).

"I got nothing to say to the Tinker family," Thomas said.

"They got something to say to you" (Shaw 73).

Gradual increase of significance of the utterances in the speech of the characters, known as the syntactic stylistic device of gradation, is illustrated by the following dialogic fragments:

"I'm very happy," he said. "Yes, indeed. Mighty happy. I got good news today, too. Special good news. That's why I waited on you out here. I wanted to tell you."

"What is it, Arnold?" (Shaw 63).

"For how long?" Fairweather asked calmly.

"I don't know. A few days. A month. Perhaps permanently" (Shaw 287). 
Additional emphatic coloring of the characters' utterances is achieved by means of the use of emphatic constructions, as may be seen from the following excerpts of dialogue:

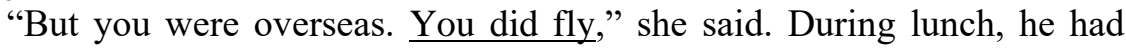
talked about England.

"A few missions. Just enough to get an Air Medal, so I wouldn't feel naked in London. I was a passenger. I admired other men's wars" (Shaw 99).

"I never did find out what happened. He never writes, of course."

"Our family," Gretchen said (Shaw 224).

Such means of extension of the syntactic structure of a sentence as detachment may be traced in the following fragment:

"He enjoyed it," Gretchen said finally. "When that boy was practically helpless and he hit him so many times. I always thought - when I thought anything about it - that it was just a man earning a living - in a peculiar way - but just that. It wasn't like that at all tonight, was it?"

"It's a curious profession," Rudolph said. "It's hard to know what really must be going on in a man's head up there" (Shaw 229).

It should also be noted that there are many examples of several syntactic stylistic devices in one dialogic exchange, as, for instance, in the following one, which contains anaphora, a parallel construction, detachment, aposiopesis and polysyndeton:

"What's the reason you don't want to be like me?"

"I'd like to have a room like yours," Rudolph said, "I'd like to have money like you and books like you and a car like you. I'd like to be able to talk like you - some of the time, anyway - and know as much as you and go to Europe like you..." (Shaw 123).

The results of the quantitative analysis of the syntactic stylistic devices in I. Shaw's literary discourse are presented in the pie chart below.

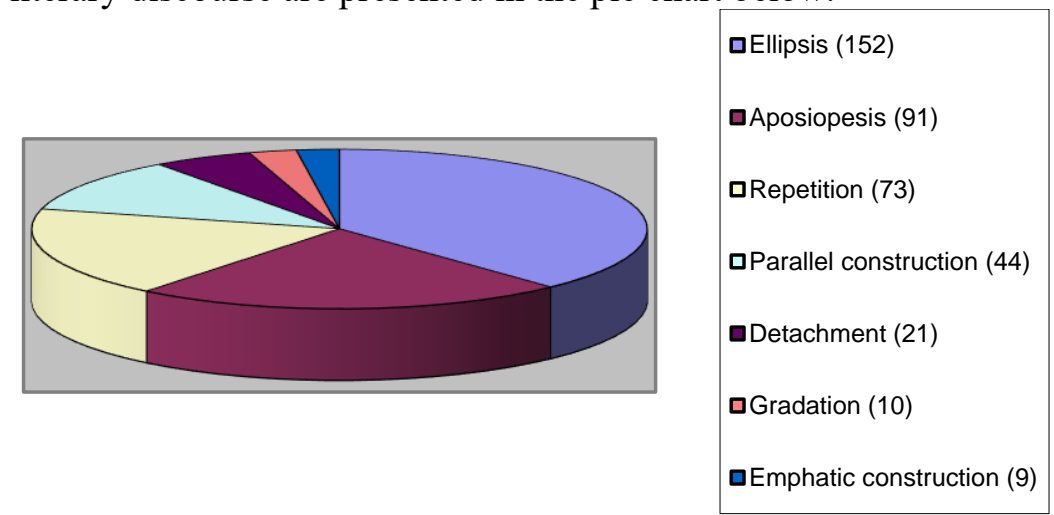

Figure 3. Quantitative characteristics of syntactic stylistic devices in I. Shaw's literary discourse 
The prevailing use of elliptical constructions (152 examples - 38\%) and aposiopeses (91 examples - 22.8\%) reflects the natural omissions that characterize colloquial speech. Extensive usage of repetitions (73 examples $18.3 \%$ ) may be explained by the common tendency of all people to repeat certain important facts, thoughts or opinions with the aim to lay the stress on them and draw the listener's attention to them. Parallel constructions (44 examples $-11 \%$ ) add rhythm to the characters' utterances.

\section{Conclusion}

Thus, at the syntactic level dialogue in fiction bears resemblance to colloquial speech. A natural direction of further research is the comparative analysis of linguostylistic peculiarities of the characters' dialogic and monologic speech in literary discourse.

\section{Works Cited}

Antonov, O., "Komunikatyvni styli personazhnoho movlennia: linhvopragmatychnyi ta sotsiolinhvistychnyi aspekty (na materiali suchasnoyi amerykanskoyi dramy)", Diss. Kyyiv, 2017.

Bakhtin, M., Voprosy literatury i estetiki, Moscow, Khudozhestvennaya literatura, 1975.

Borysenko, N., "Personazhne movlennia yak vidobrazhennia sotsialno-statusnykh kharakterystyk komunikantiv (na materiali brytanskoyi dramy)" in Movni $i$ kontseptualni kartyny svitu, Vol 45, 2013.

Dolinin, K., Interpretatsia teksta: frantsuzskiy yazyk, Moscow, KomKniga, 2010.

Goncharova, Y., Puti lingvisticheskogo vyrazhenia kategorii avtor-personazh $v$ khydozhestvennom tekste, Tomsk,: Izdatelstvo Tomskogo universiteta, 1984.

Igina, Z., "Modalni slova u personazhnomu movlenni: semantychnyi ta pragmatychnyi aspekty (na materiali anhliiskoho i amerykanskoho modernizmu.", Diss. Kyyiv, 2009.

Kaushanskaya, V., Revekka Kovner, Olga Kozhevnikova, Yelena Prokofieva, Zinaida Raines, Sarra Skvirskaya and Frida-Debora Tsyrlina, A Grammar of the English language, Sankt-Peretburg, Ayris-press, 2008.

Khalizev, V., Teoriya literatury, Moscow, Vysshaya shkola, 2002.

Kukharenko, V., Interpretatsia teksta, Odessa, Latstar, 2002.

Nera, N., "Hendernyi aspekt nevlasne-priamoho movlennia v anhlomovnomu dyskursi (na materiali zhinochoyi prozy pershoyi polovyny XX stolittia)", Diss. Lviv, 2017.

Romaniuk, I., "Dialoh v opovidnomu teksti: strukturno-semantychni ta stylistychni funktsiyi”, Diss. Odessa, 2010.

Shaw, I., Rich Man, Poor Man, New York, Dell Publishing Co., Inc., 2005.

Valgina, N., Teoriya teksta, Moscow, Logos, 2003.

Yakubinskiy, L., Yazyk i yego funktsionirovaniye, Moscow, Nauka, 1986. 
3. Linguaculture 1, 2020

Zahnitko, A. and Iryna Domracheva, Osnovy movlennievoyi diyalnosti, Donetsk, Ukrayinskyi kulturolohichnyi tsentr, 2001.

Zemskaya, Y., Russkaya razgovornaya rech. Lingvisticheskiy analiz $i$ problemy obuchenia, Moscow, Flinta, Nauka, 2011.

\section{BIONOTES}

IRYNA MYKYTIUK (associate professor) is an English and Stylistics lecturer at Yuriy Fed'kovych Chernivtsi National University. She received her Ph.D. in Linguistics (Germanic Languages) with a thesis "Functioning of Secondary Compositionally Conditioned Nomination in a Literary Text (on the material of English short story)" in 2003. She is an author of over 100 publications among which there are 14 manuals on Stylistics and Text Interpretation and 2 textbooks on Translation Studies. Her research areas include: Theory of Nomination, Stylistics, and Translation Studies.

Email: imykytiuk@gmail.com

OLESIA MUSURIVSKA (associate professor) is an English and Lexicology lecturer at Yuriy Fed'kovych Chernivtsi National University. She received her Ph.D. in Linguistics (Germanic Languages) with a thesis "Lexical-semantic Group of Adjectives with the Meaning 'Firm' in the English Language" in 1993. She is the author of over 40 publications among which there are 4 manuals on Text Interpretation. Her research areas include: Semantics, Lexicology.

Email: levungur28@ukr.net 